\title{
Digital Financial Services in Pakistan: Opportunities, Challenges and Suggestions
}

\author{
Rabia Manzoor* $\quad$ Asif Javed $^{\dagger} \quad$ Vaqar Ahmed ${ }^{\ddagger} \quad$ Abdul Rauf $\S$
}

\begin{abstract}
This study examines how the financial services accessed and delivered through digitalization in Pakistan. Digital infrastructure refers to Internet, mobile phones, ATMs, tablets, chips, biometric devices and any other existing digital communication system. Currently, financial markets have become more reliant on digitalization as digital integrated financial markets are playing an important role in the development of financial sector, increase market competitions, performance of intermediaries and the efficiency in their daily operations. Based on secondary data and stakeholders' interviews, the study provides an overview of digital financial inclusion, explores the possible opportunities and key challenges to digital financial services in Pakistan. Over time, Pakistan has made efforts to develop and integrate several digital financial services systems. It identifies that lack of coping mechanisms for systemic risks, weak infrastructure, underdeveloped technology ecosystem, low income and financial literacy rate, inadequate banking facilities and low level of formal institutions. It concludes that a greater understanding of digital financial services in economies, promotion of investors' confidence and long-term interests, greater competition and trade in IT and ICT products and corporate governance can help to promote digital financial services. Digital technology is not enough to increase the financial inclusion, well developed payments system, consumer protection safeguards, good physical infrastructure and appropriate regulations are required to foster the digital financial services.
\end{abstract}

Keywords: Digital finance, financial inclusion, financial services digital trade.

\section{Introduction}

This paper aims to investigate digitalization in the financial services with a particular focus on challenges and opportunities in digital innovation in Pakistan. Digital financial services can be defining as when basic financial services such as payments, credit, saving, insurance, and remittances are accessed and delivered through digital channels through internet, ATMS (Automated Teller Machines), mobile phones, tablets, biometric devices, electronically enabled cards, and POS (Point-of-Sale) etc (AFI 2016) ${ }^{1}$. These technologies used over point of sale (POS) devices that connecting individuals and businesses to a digitized payment system, enabling speedy, transparent, and seamless transactions across all parties. Digital financial services are playing an important role in providing range of affordable, secure, and convenient banking services to all over the world whereas it

\footnotetext{
*PhD Candidate, Department of Economics, Clark University, USA. Email: rmanzoor@clarku.edu

${ }^{\dagger}$ Research Associate at Sustainable Development Policy Institute (SDPI), Islamabad, Pakistan. Email: asifjaved@sdpi.org

${ }^{\ddagger}$ Joint Executive Director at Sustainable Development Policy Institute (SDPI), Islamabad, Pakistan. Email: vaqar@sdpi.org

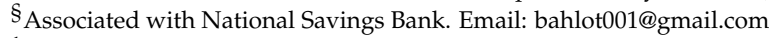

${ }^{1}$ Alliance for Financial Inclusion.
} 
also permits business and individuals to carry out seamless transactions (Kumar et al., 2019). Particularly, digital financial services are enabling developing countries to greater economic stability and reducing income inequality.

Over the time, financial markets have become more reliant on digitalization as it is an important tool for the development of financial sector. Individuals, businesses, and government are taking advantages of digital financial systems by domestic savings, lending, smooth consumption, insurance products, investments, increase market competition, performance of intermediaries, efficiency in their daily operations and greater economic growth. On the other hand, digitalization is pushing the organizations to bring innovative changes in their business models (Bharadwaj, El Sawy, Pavlou, \& Venkatraman, 2013). In Pakistan, generally the concept of digital financial market becomes more important after the globalization which has allowed investors to invest freely with low risk and higher returns particularly in stock markets. Government of Pakistan and Central Banks are working for making the banking systems more inclusive through digitalization. According to an estimate, the digital finance services market potential will be more than \$ 36 billion by 2025 which will also increase GDP by 7\% and help in generating 4 million new jobs.

The State Bank of Pakistan has launched National Payment System Strategy (NPSS) for a digital payment network in the country. In Pakistan, the digital financial services have been started in 2008 after adopting the branchless regulations. In 2015, the growth of financial services has been increased as country approved the national inclusion strategy with aims to build a dynamic and inclusive financial system. These policies encouraged the digital financial service providers to increase the private sector investment in microfinance institutions. Therefore, telebanking, internet banking, ATM, credit and debit cards have emerged as effective delivery channels for traditional banking products. Telenor, a leading mobile phone service is one of the best examples of a non-banking system as offering the basic financial services to communities such as easy paisa. In easy paisa services, people can open a bank account, transfer funds, deposits, or withdrawal money, make mobile payments and utility bills. Nearly, it has 7.5 million registered accounts and more than 7 million are over the counter users.

Government of Pakistan is also using the digital financial services in benefit transferring programs such as Benazir Income Support Programme in 2010 began to digitize safety net support to 6 million poor women. In 2014, Pakistan became a member of the United Nations' 'Better Than Cash Alliance', which encourages governments around the world to use digital payments. E-Pay Punjab if the first ever government payment gateway for the ease of business and facilitation of citizen which takes care of all Business to Government (B2G) and Public to Government (P2G) payments ${ }^{2}$. Similar initiatives for paying taxes through digital portals have taken by Sindh, Khyber Pakhtunkhwa and Balochistan. Despite these efforts, progress is found slower than expected as 2017 Global Findex survey revealed only modest growth in digital financial services. According to report, the percentage of adults with accounts rose only 8 percentage points from 2014 to 2017 by bringing the total to 21 percent. The survey also reports the widening gender gap

\footnotetext{
${ }^{2}$ ePay Punjab, https://epay.punjab.gov.pk/
} 
in Pakistan as in 2014, 21 percent of men had accounts, and this number increased to 34 percent in 2017. By contrast, the percentage of women with accounts increased from 5 to 7 percent. This means that men are now roughly five times more likely than women to have an account.

Although there is varied literature available on digital financial system in Pakistan but there is clearly a knowledge gap in understanding that why the progress in slower than expected. This relatively new scenario has opened the door for researchers to work on digital financial services. Various studies have been done on this area; some researchers have pointed out the public mistrust on these services as more than a third of adults do not trust on financial institutions. While World Bank reported the weak infrastructure in Pakistan such as underdeveloped payment systems, customer credit data and Internet coverage. An indigenous understanding and evidence of the problem is clearly missing. Unfortunately, no one explore the challenges and prospects of digital financial services in Pakistan. Thus, more research needs to be done to explore the challenges therein along with assessing the nature and magnitude of these problems and develop solutions accordingly.

\section{Literature Review}

Digital innovation is transforming the financial services industry (Chishti \& Barberis, 2016). Innovative financial technology is known as fintechs, which are developing innovative technology-based solutions by addressing emerging customer demands and with user-centered approaches (Christensen, 2013). Most of the fintechs combine financial services with additional activities which are linked with sharing economy businesses, ecommerce, and big data analytics in order to provide modern added value. Advanced technologies like artificial intelligence, machine learning, distributed ledger technologies and cognitive computing compliment the traditional incumbents and new entrants in Fintech (IOSCO, 2017) Fintech are assisting farmers through connecting them with banks and investor (Javed, 2020a). Fintechs have also enhanced the efficiency and spread of financial industry through innovative and easier financial products and solutions which are available at lower costs. This has enabled the financial inclusion of poor segment of society which were financially excluded previously.

The competition between traditional firms has increased due to digitization while it also creates new opportunities for firms with distinct business models like crowd funding platforms, peer-to-peer lending, and digital-only banks (Rizvi, Naqvi, \& Tanveer, 2018). Kumar, Mishra, and Saha (2019) highlighted those digital financial services are currently popular in urban areas while the demand also exists from rural areas, non-earning techsavvy youth and migrants, and the financial services providers should also focus on these groups. E-commerce and social media markets are increasing while the growth cycle of digital platforms is also expanding. This has become possible based upon new innovations in payments and financing which are being introduced by the internet companies and not by traditional banks (Dapp, Slomka, AG, \& Hoffmann, 2014). McCaffrey and Schiff (2017) pointed out that internet-based solutions which involved using a mobile de- 
vise appears to be more appropriate as compared to transfer cash physically or for making online bank transfers.

Digitization in retail banking has helped in reducing the time spent on operational activities. With more advancement in digital and mobile technology, the financial services will ultimately be shifted towards online digital platforms. Anikina, Gukova, Golodova, and Chekalkina (2016) stated that new technology has made it possible to access information related to financial services and the technology has also helped in decreasing the costs and improving service delivery. Lusardi and Mitchell (2014) pointed out that the financial inclusion focuses on the access to finance and financial literacy. Cole, Sampson, and Zia (2011) examined that the financial literacy is a significant forecaster of financial behavior in developing countries.

Micro Small and Medium Enterprises (MSMEs) in Pakistan find it difficult to complete the traditional compliance requirements of financial institutions regarding access to credit and fixed investment. UNDP's (2016) survey revealed examined that woman enterprises in Pakistan have limited access to financial resources while the different schemes announced by the government have low level of efficiency. Trade with other South Asian countries can be increased through developing E-banking initiatives among member states which will help in settling trade related payments and decrease the dependence upon traditional financial institutions (Manzoor, Maken, Syed, \& Ahmed, 2018). Javed (2019) also highlighted that there is lack of bilateral financial across South Asian region while the financial sector of Pakistan is the most restrictive services sector as the services trade restrictiveness index is higher for financial services as compared to another services sector (Manzoor, Maken, Syed, \& Ahmed, 2019).

\section{Research Gaps}

Perhaps, the most pertinent problem encountered while examining and analyzing information from secondary sources was the dearth of information regarding the extent of digital financial market services in Pakistan. The various processes of financial services were only confined to official sources and unfortunately it has not been explored in the literature produced by private sector associations. There is literature available in understanding how Pakistani digital financial sector is benefiting to Pakistani people after system is deepened. Limited research is available that investigates opportunities and challenges in digitalization and financial services in Pakistan. Therefore, this study aims to provide the progress towards improving policy and regulatory environment and identify key challenges to expansion of digital financial services.

\section{Research Approach and Methodology}

Our research methodology relied on three key instruments to approach our research questions. First, a selective body of literature, inclusive of the various approaches to ascertain the situation of digital financial services in Pakistan was reviewed. The data analysis, guided by context analysis and structural assessment, was used to determine the presence 
of certain concepts in literature. The study extracts the most recent data for the variables and used the descriptive analysis for presenting the results. Data for variables such as percentage of adults with accounts, formal financial services, e-commerce transactions, e-banking infrastructure and accounts by income is used in the study while the data is extracted from State Bank of Pakistan and Global Findex database. The recent scientific papers were reviewed comprehensively to determine the recurring themes and to gauge its congruence in the context of the data collected from other qualitative sources.

Similarly, the structural assessment of the literature involved examining and evaluating the key components of digital financial services, including, payments, credit, saving, insurance and remittances through digital channels through internet, ATMS (Automated Teller Machines), mobile phones, tablets, biometric devices, electronically enabled cards and POS (Point-of-Sale) etc. This was done to appraise the current and potential challenges in Pakistan along with identifying the potential reforms for the promotion of digital financial services. The key inputs are also included from the Focus Group Discussion held at 21st Annual Sustainable Development Conference (2020). Participants included the government officials, representatives from academia, experts from private and development sector and other related persons.

\section{Empirical Analysis}

Based on the above-mentioned methodology, key quantitative and qualitative findings are given below. In the subsequent section, we also identify those government institutions, which would be responsible for possible implementation in future. The results indicate that only limited people are financially included in Pakistan. However, with the rise in startups in IT field, provision of digital financial services has increased considerably. There are certain challenges in the expansion of digital financial services which include risk, lack of trust and higher operating cost.

\section{Overview of Digitalization in Pakistan's Financial Markets}

This section provides an overview of the status of digitalization in financial markets. It contains an analysis of adults with accounts, financial institutional accounts, formal financial services and users in Pakistan.

\section{Adults with Accounts}

The adults with accounts in financial institution show how much population is financial included. Less the percentage means that less number of people is financial included and only a marginal percentage is getting benefits of financial services.

The percentage of adults with accounts in Pakistan is lower as compared to other South Asian countries while only Afghanistan has lower percentage than Pakistan. The percentage of adults with accounts in Pakistan was 13\% in 2014 which increased to $21 \%$ in 2017. As contrary to this, the percentage of adults with accounts was $80 \%$ in India and 
$74 \%$ in Sri Lanka. It is clear from the graph that in Pakistan very few people are having bank accounts while greater access to account allows people to store money, send and receive payments. In this way, they can plan to better manage their life in unexpected emergencies. Moreover, people can use these financial services such as credit and insurance to invest in education, health, start and expand their businesses, manage risks which improve their lives.

Figure 1

Percentage of adults with accounts in South Asia

Source: Global Findex Database

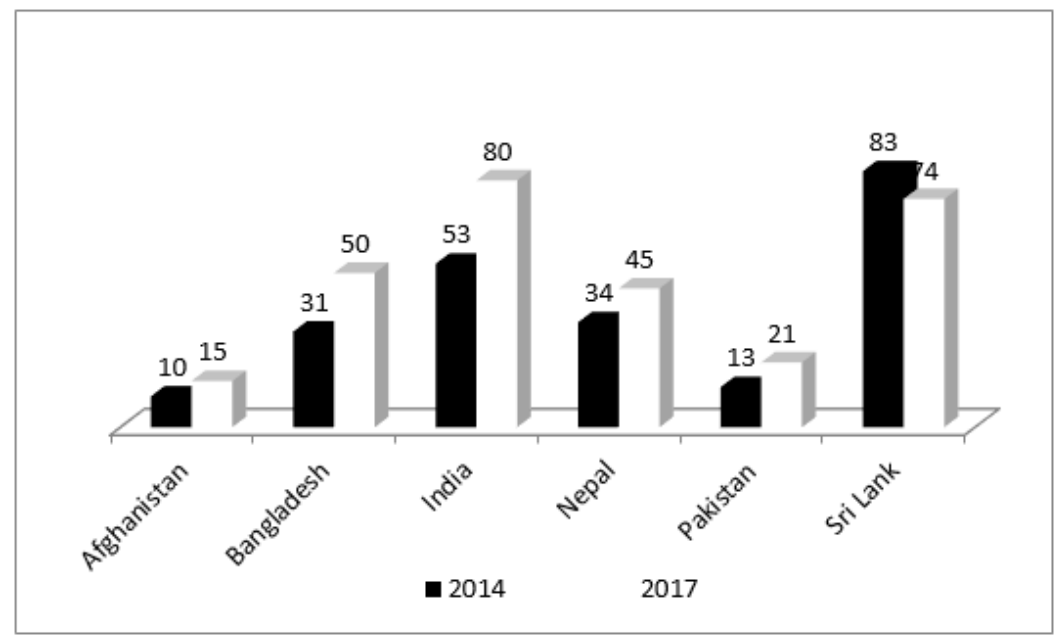

Figure 2

Percentage of adults with accounts in Pakistan

Source: Global Findex Database

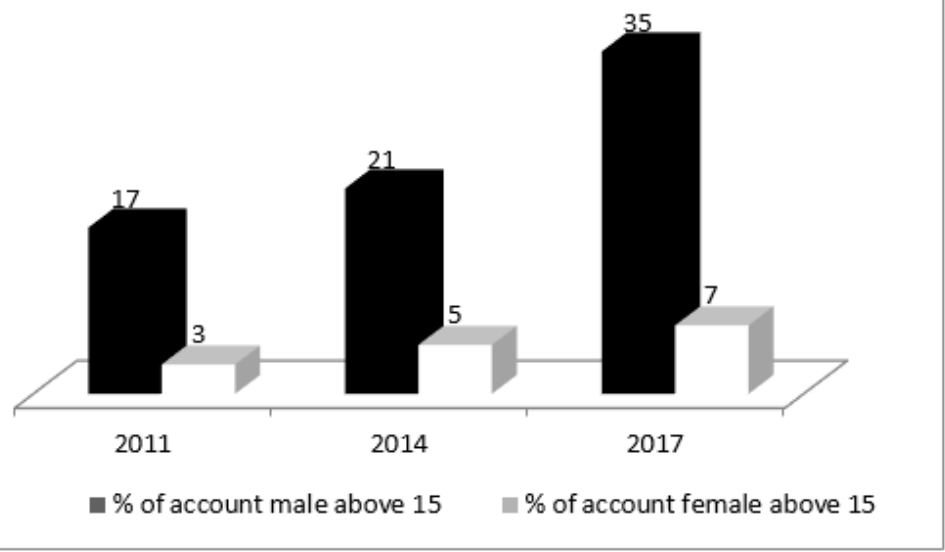


The figure- 2 points out that the $17 \%$ percentage of male aged $15+$ in 2011 had account at a bank or any type of other financial institution. The percentage increased to $21 \%$ in 2014 and 35\% in 2017. However in comparison to this, the percentage of females with account is quite low as only 3\% of female had bank account in 2011 and the percentage marginally increased to $7 \%$ in 2017 . This shows that still females are financially excluded while the percentage of male is also not very encouraging.

\section{Financial Institution Account}

Financially included persons are those individuals who have an account in their name with a full-service financial institution. Banks, nonbank financial institutions like deposit taking microfinance institutions (MFIs), mobile money service providers and financial cooperatives are included in full-service financial institutions.

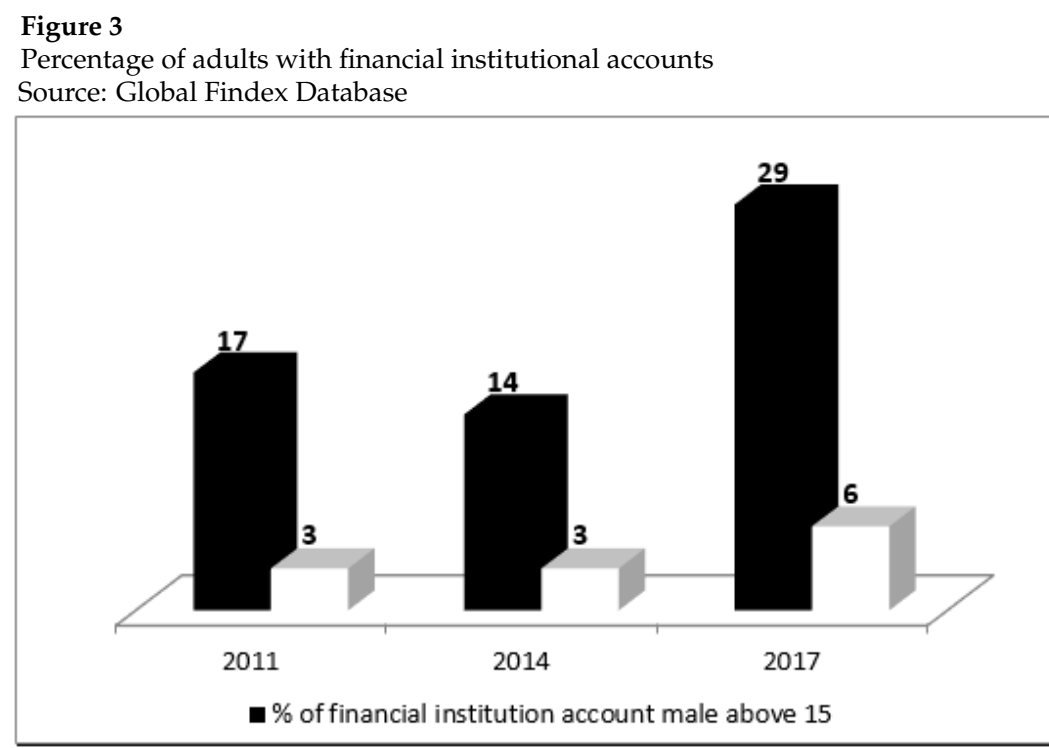

The figure 3 highlights that only a small portion of population aged $15+$ has financial institution account. In 2011, 17\% of male had financial institution account, and the percentage increased to $14 \%$ in 2014 and $29 \%$ in 2017. As compared to this $41 \%$ male in Bangladesh, $83 \%$ in India and $74 \%$ in Srilanka has financial institution account. On the other side, only 3\% of female in Pakistan had financial institution account in 2011 which increased to merely $6 \%$ in 2017.The progress towards financial inclusion is slow and it retards the MSMEs particularly woman enterprises to attain credit and access to financial services. 


\section{Formal Financial Services and Users}

Formal financial services and users have increased over the past few years in Pakistan. The surge in startups especially in the IT field has also revolutionized the provision of financial services. Number of mobile phone users particularly the smart phone users increased in Pakistan which provides bases for digital financial services. Currently, smart mobile phones are providing the advantages of banking to those people who have long been dismissively overlooked as unbanked. Through the mobile services, people can deposit and withdraw money, open and manage saving accounts, transfer money to friends and family. Moreover, through the mobile technology people can pay their utility bills, medical bills, school fees, etc without wasting their time and miss work. Therefore, access to mobile technology is lifting the bane of cash dependency and opening a door to sustainable and quality of lives.

Table 1

Formal financial services

\begin{tabular}{lcccccccc}
\hline \multirow{2}{*}{ Description } & \multicolumn{4}{c}{ Fiscal Year 17 } & \multicolumn{4}{c}{ Fiscal Year 18 } \\
\cline { 2 - 8 } & Q1 & Q2 & Q3 & Q4 & Q1 & Q2 & Q3 & Q4 \\
\hline ATM & 11,803 & 12,352 & 12,515 & 12,689 & 12,963 & 12,963 & 13,85 & 14,019 \\
Internet Banking Users (Thousand) & 2,057 & 2,179 & 2,337 & 2,347 & 2,781 & 2,677 & 2,888 & 3,114 \\
Mobile Phone Banking Users (000) & 1,253 & 1,510 & 1,672 & 2,484 & 2,712 & 2,886 & 3,114 & 3,386 \\
Credit Cards (000) & 1,212 & 1,209 & 1,248 & 1,292 & 1,334 & 1,374 & 1,424 & 1,454 \\
Debit Cards (000) & 17,473 & 17,470 & 17,543 & 17,858 & 18,779 & 19,848 & 20,985 & 21,712 \\
Number of Transactions (000) & 462 & 523 & 529 & 563 & 557 & 600 & 652 & 709 \\
Number of Transactions (Rs. Millions) & 91,420 & 92,483 & 95,631 & 102,218 & 105,393 & 106,709 & 112,438 & 122,222 \\
\hline Source: State Bank of Pakistan & & & & & & & &
\end{tabular}

State Bank of Pakistan has launched National Payment Systems Strategy (NPSS) and MPG initiative paves way for a digital payments network in Pakistan ${ }^{3}$. The number of internet banking users has increased considerably since start of FY 17 (table 1). Internet banking users were 2,057 thousand in Quarter 1 of FY which increased to 3,114 thousand at the end of Q4 FY 18 showing increase of 51\%. Kombe and Wafula (2015) pointed out that the internet banking and ICT adoption helps in improving the financial performance of commercial banks. Similarly, ICT sector can help in promoting the access towards digital services (Javed, 2020b). Mahmoodi and Naderi (2016) also emphasized on the same point that the adoption of ICT and innovative solutions promotes efficiency and effectiveness of services of the banking sector. Payment through internet has also increased in Pakistan as the number of transactions showed growth rate of 53\% from Q1 FY 17 to Qe4 FY 18. Government is also committed to promote digital payment gateways in Pakistan as it is not only providing broader opportunities to businesses and individuals, but it also assists in increasing government's revenues ${ }^{4}$. Recently, SBP has allowed the pilot

\footnotetext{
${ }^{3}$ Growth of digital financial services in Pakistan: Need of more improvement measures and investment in tech banking'. The Economist, December 16th 2019, http:/ / www.pakistangulfeconomist.com/2019/12/16/growth-of-digital-financial-services-in-pakistan-needof-more-improvement-measures-and-investment-in-tech-banking/

${ }^{4}$ Digital payments, promoting financial inclusion in Pakistan' Technology Times Pakistan, July 16th 2020, https://www.technologytimes.pk/2020/07/16/digital-payments-promoting-financial-inclusion-in-pakistan/
} 
operation of e-commerce payment gateway to start its operation ${ }^{5}$.

The capital market industry in Pakistan is in a transitional period where the market has an opportunity to leverage data, design, and superior technology to make investment convenient (Pakistan Microfinance Network, 2019). Besides this, digital information platforms are providing a one-stop-shop for financial information regarding entire market which includes inclusive overviews of credit cards, powerful insights about the investment options and stock market and investment. Financial institutes in Pakistan are adopting the usage of distributed and decentralized ledger technology through which improvement has taken place in payments, data management of assets, audit and clearing and settlement.

The inflow of direct and portfolio investment from China in Pakistan promotes financial integration among the two countries. Along with this, cross-border expansion of financial institutions with at least one branch of a commercial bank having been established between both countries also strengthens the financial integration process. Commercial cooperation between the financial institutions particularly banking entities in both economies can be strengthened if the private sector from both countries engages overtime in joint ventures. And the same can be done with other Asian and other countries for promoting financial integration.

Table 2

E-commerce transactions

\begin{tabular}{lcccccccc}
\hline \multirow{2}{*}{ Description } & \multicolumn{4}{c}{ FY 17 } & \multicolumn{4}{c}{ FY 18 } \\
\cline { 2 - 8 } & $\mathbf{Q 1}$ & $\mathbf{Q 2}$ & $\mathbf{Q 3}$ & $\mathbf{Q 4}$ & $\mathbf{Q 1}$ & Q2 & Q3 & Q4 \\
\hline Number of e-commerce transactions (000) & 203 & 264 & 338 & 412 & 827 & 840 & 807 & 948 \\
Amount of e-commerce transactions (Rs. Million) & 1,774 & 2,041 & 2,424 & 3,158 & 4,754 & 4,421 & 4,446 & 5,056 \\
\hline Source: State Bank of Pakistan & & & & & & &
\end{tabular}

The table 2 shows that the number of e-commerce transactions increased significantly from 203 thousand transactions in Q1 FY 17 to 948 thousand in Q4 FY 18. The amount of e-commerce transactions also increased during the time period. Online markets growth demonstrates that Pakistan possesses immense potential in ecommerce market. This has become possible based upon lower transaction costs, increase in internet penetration and convenience (Javed, 2020a). Many new players and startups are entering in the market which will further develop the online markets in Pakistan. However, the number of eretailer is around 2,000 which is still quite low as compared to traditional retail market where the number of retailers is more than 900 thousand.

\section{Challenges to Digital Financial Services}

Most of our respondents were of the view that topmost key challenges to digital financial services are risk of using digital services, lack of trust and high operating cost in Pakistan which triggers further challenges of digital financial services as shown in below graph.

\footnotetext{
${ }^{5}$ SBP allows pilot operation of e-commerce payment gateway' Profit Pakistan, July 18th 2020, https:// profit.pakistantoday.com.pk/2020/07/18/sbp-allow-pilot-operation-of-e-commerce-paymentgateway/
} 


\section{Low levels of Formal Financial Services}

Financial inclusion in Pakistan is quite low as the major portion of population does not have access to formal or informal financial services. According to Global Findex Database (2017), 99 million adults do not have a bank account. This shows that a major portion of population is financially excluded and do not avail the formal financial services.

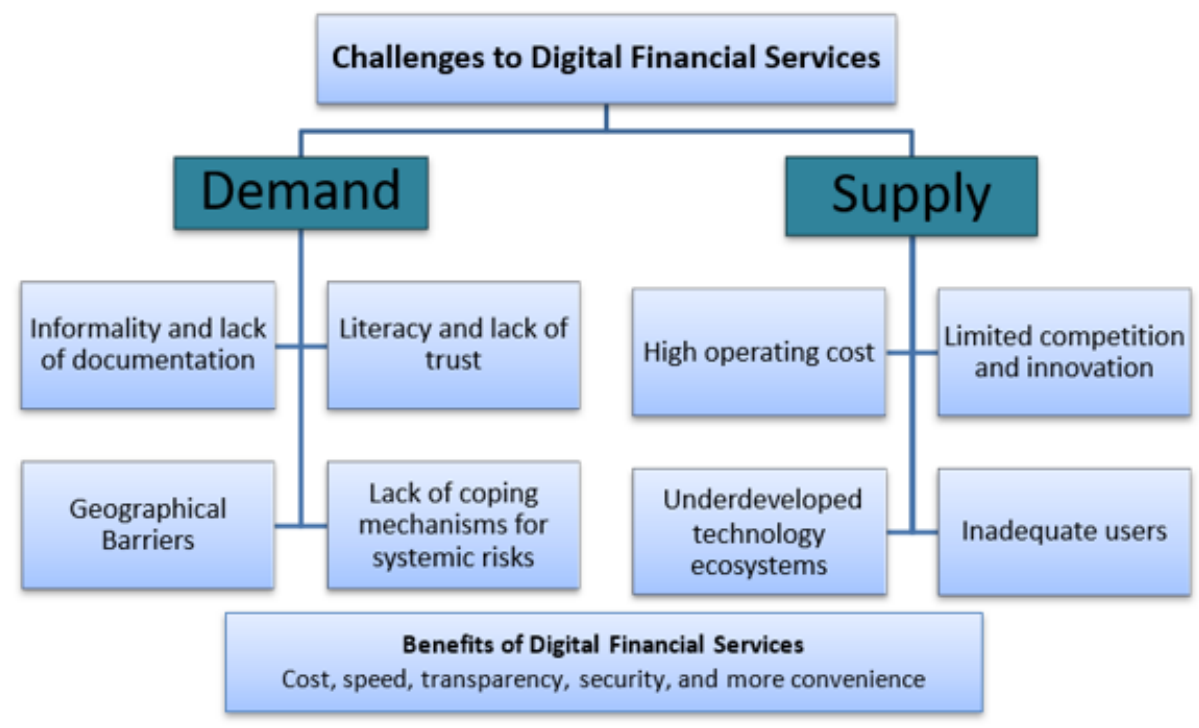

Source: Authors

Table 3

E-banking Infrastructure

\begin{tabular}{lcccccccc}
\hline \multirow{2}{*}{ Description } & \multicolumn{4}{c}{ FY 17 } & \multicolumn{4}{c}{ FY 18 } \\
\cline { 2 - 8 } & Q1 & Q2 & Q3 & Q4 & Q1 & Q2 & Q3 & Q4 \\
\hline Number of bank branches & 13,792 & 14,219 & 14,193 & 14,293 & 14,422 & 14,422 & 14,850 & 14,970 \\
Real Time Online Branches (RTOB) & 13,499 & 13,926 & 13,899 & 14,150 & 14,285 & 14,610 & 14,710 & 14,850 \\
Point of Sale (POS) & 51,009 & 52,062 & 52,854 & 54,490 & 49,929 & 49,929 & 53,509 & 53,511 \\
\hline Source: State Bank of Pakistan & & & & &
\end{tabular}

It can be observed from the table 3 that although the number of bank branches has increased gradually from Q1 FY 17 to Q4 FY 18, however the number of branches is still not enough as compared to the population size of Pakistan. Similarly, the branches are concentrated in major cities while the financial services of banks are still not available at a wider level in rural areas. To strengthen the financial services, a respondent claims that digital financial services allow poor to conduct financial transactions through mobile devices and use retail agents to send money or digital balance to cash. Another respondent suggested that utility providers should offer attractive offers to pay utility bills digitally as many people in Pakistan are still using the cash method to pay their bills. 


\section{Inadequate Banking Facilities}

Problems relating to the low use banking services in Pakistan have been observed and this is due to a combination of factors, including low income, illiteracy, and poor knowledge of the banking system, the remoteness of structures, lack of infrastructure, long procedures for opening an account, high cost of services and lack of information. In China, nearly 08 out of 10 adults have a bank account. In addition, Pakistan had around 9 ATMs for every 100,000 adults as of 2015, compared to 76 for China. In fact, China had almost as many ATMs per 100,000 adults back in 2006, as we have today. This indicates that China has leveraged technology and digitization to expand financial access. As Pakistan expands its banking inclusion programme, it can help a larger segment of rural population to get integrated with the formal financial sector inside and outside Pakistan. To bolster the banking services, a respondent suggested that private sector could be helpful in promoting the financial services by paying the wages to worker through digitizing. In Pakistan, mostly people are working in private sector and paid in cash.

\section{Top Reasons for not Registering a Bank Account}

Figure 4

Top Reasons for not registering a bank account

Source: Financial Inclusion Insights (2017)

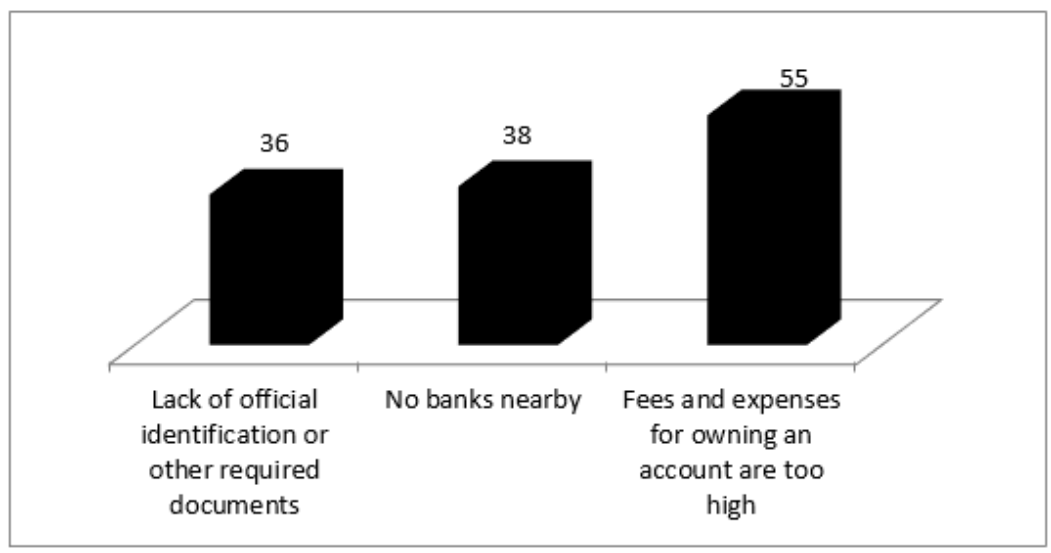

High cost of banking infrastructure restricts the spread of financial services at a wider level (Ali \& Abdullah, 2020). The table 6 shows that 55\% people from a survey result pointed out the fees and expenses for owning an account are too high which is why they do not register a bank account. Lack of bank branches and official identification and related documents are other major reasons of not registering a bank account. A respondent suggested that small value financial services with simplified procedures could be helpful in fostering the digital financial services. 


\section{Low Income and Financial Literacy Levels}

Financial literacy plays a significant role in economic development of a country while it also influences the consumer behavior regarding budget, managing saving, investment funds and income (Lusardi \& Mitchell, 2014; Taft, Hosein, Mehrizi, \& Roshan, 2013). Financial literacy is defined as understanding of investors and consumers related to different concepts and products. Financial awareness is also important because with this understanding, persons are more prepared to handle the financial issues and they can plan and manage their funds more effectively (Taft et al., 2013). A respondent explained that first time users in Pakistan often have inadequate awareness of financial services and skills to understand and responsible use them. Therefore, he suggested through strong financial consumer protection frameworks and adequate financial literacy we can foster the digital financial inclusion.

However, the situation in Pakistan is not encouraging as there exists lack of awareness regarding usage of digital channels or digital technologies among households particularly females (Zulfiqar, Chaudhary, \& Aslam, 2016). The study pointed out that due to more exposure to the different financial activities, male persons are more aware regarding the various concepts of the finance as compared to the female in Pakistan. Likewise, more educated persons are having better understanding of the financial products and services.

\begin{tabular}{|c|c|c|}
\hline Year & $\begin{array}{c}\text { Account, income, } \\
\text { poorest } 40 \% \\
(\% \text { ages } 15+)\end{array}$ & $\begin{array}{c}\text { Account, income, } \\
\text { richest } 60 \% \\
(\% \text { ages } 15+)\end{array}$ \\
\hline 2011 & $5 \%$ & $14 \%$ \\
\hline 2014 & $10 \%$ & $15 \%$ \\
\hline 2017 & $14 \%$ & $26 \%$ \\
\hline
\end{tabular}

The table 4 indicates that in 2017, only $14 \%$ of person belongs to income group of poorest $40 \%$ have account as compared to $26 \%$ from richest $60 \%$ income group. This shows that income level also affects the behavior of person towards financial inclusion in Pakistan. And the percentage of people having account is more among higher income group as compared to lower income group.

\section{Underdeveloped Technology Ecosystems}

Due to lack of digitalization in microfinance industry, the number of borrowers in Pakistan is lower as compared to regional economies (Pakistan Microfinance Network, 2018). Although branchless banking has grown significantly but still the customers in remote areas do not have access to delivery channels and they are dependent upon traditional banking channels such as cheques. As per Global Findex database (2017), only 19\% of rural population in Pakistan has account at a bank or any type of other financial institution. The percentage is quite low if we compare it to India (79\%) and Bangladesh (40\%). 


\section{Weak Infrastructure}

A study by ZTBL (2019) indicates that poor IT infrastructure, lack of relevant and trained resources, fear of financial disruption and lack of framework for partnering with Fintechs are major issues which are restricting the usage of digital technology in financial market institutes. Financial system in Pakistan is not well developed and requires greater upfront investment. Mobile wallet accounts are also mostly inactive as out of more than 38 million mobile wallet accounts, $53 \%$ are inactive because of absence of convenient option to use the funds for day-to-day transactions ${ }^{6}$.

\section{Lack of Coping Mechanisms for Systemic Risks}

Currently, there is no mechanism in place to handle systemic risks. Legally, all digital financial services in Pakistan should undertake the function of preventing and reconciling systemic risks and maintaining national financial stability at their end. For this strengthened cooperation between private and state-owned commercial, investment and intermediary banks will be required. Owing to lack of information sharing, Pakistan lack systems for measuring, analyzing, warning and controlling systemic risks in all offering digital financial services. A respondent explained that digital financial services such as digital lending could pose risks to individual institutions, particularly if they are left unregulated. Therefore, strong frameworks for systemic risks are very necessary to develop.

\section{High Operating Costs}

Most of the financial services are operating expensive and outdated core technologies and still relying on time consuming human and paper processed. Therefore, high operating costs make low balance accounts unprofitable. According to respondents, digital financial services should be automated, transparent, tailored to customer needs and delivered remotely at lower costs. A respondent claimed that if simple mobile phones get access to financial services it could help to overcome the barriers of unbanked adults. In this way, people from remote areas can easily get access to financial services and lowering the cost might be increasing their affordability. Therefore, financial services can be designed to better meet the financial needs of the poor (Manzoor et al., 2019).

\section{Conclusion \& Policy Recommendations}

This study was conducted with the aim to explore the possible opportunities arising from digital financial services in Pakistan. Additionally, the study also aimed to examine the key challenges in the area and to evaluate key reforms and policy measures necessary for improving the digital financial services in Pakistan.

\footnotetext{
${ }^{6}$ ‘53\% of mobile wallet accounts in Pakistan are inactive: Report' ProPakistani, Dec 12th 2018, https:/ / propakistani.pk/2018/12/12/53-of-mobile-wallet-accounts-in-pakistan-are-inactive-report/
} 
Using a qualitative methodology, secondary data, and key informant interviews to see what are the possible opportunities for digital financial services in Pakistan? We also wanted to document their perceptions regarding key challenges in the system. And what should be done at the policy and implementation levels to improve the services? An additional interest was to also learn how other emerging market economies are improving their digital financial service systems in their countries?

It concludes that a greater understanding of digital financial services in economies, promotion of investors' confidence and long-term interests, greater competition and corporate governance can help to promote digital financial services. Digital technology is not enough to increase the financial inclusion, and well-developed payments system, consumer protection safeguards, good physical infrastructure and appropriate regulations are required to foster the digital financial services.

The paper provides a roadmap for the promotion of digital financial services and calls for appropriate regulatory measures. In this regard, specific roles of Ministry of Planning Development and Reforms, State Bank of Pakistan, Competition Commission of Pakistan, Securities and Exchange Commission of Pakistan and Pakistan Stock Exchange on Pakistan side have been highlighted. We suggest that there is a room for further research, and a detailed enterprise-level survey is recommended to assess the preparedness of Pakistan's digital financing sector to integrate with their counterparts.

Based on the key findings the study proposes the following policy recommendations. Digital financial services can only be promoted with the effective policies and strategies along with their implementation in true spirit. For digital financial services to flourish, behavioral change of individuals is required whereas service provide should also understand the requirements of people. There is need to raise the awareness among common people regarding usage of digital channels or digital technologies. It is required to do effective legislation regarding ICT and the regulatory authorities should implement the policies in this regard. Investment in ICT infrastructure particularly in rural areas is required to increase the financial inclusion. Consumer protection acts and laws are required which can increase the usage and adoption of ICT tools and instruments for businesses and individuals. Effective regulations for fintech are required to raise the investment from local investors. The focus should also be to develop partnership platforms for fintech incumbents and investors. The documentation process for opening a bank account should be simplified while the fees and expenses for owning an account should also be reduce so as more individuals opt to have bank accounts.

Through appropriate measures by the State Bank of Pakistan, Cross-Border Inter-Bank Payment System (CIPS) should be strengthened. This will not only prevent the usage of a third currency in bilateral trade and investment but also increase capital mobility. To ensure financial stability, the cognizance of legal and regulatory procedures should be factored into the forecasting frameworks and decision-making of regulators and policy makers so as to ensure financial stability. The Ministry of Planning, Development and Reform may evaluate multiple avenues like the Asian Infrastructure Investment Bank (AIIB) for financing development projects on Built-operate-transfer (BOT) basis. AIIB may also be invited to promote "export credit, project financing, syndicated loan, trade finance, investment bank, cross-border RMB business, financial market, assets management, e- 
bank, and financial lease. Besides, it may support the project financing by RMB loans and establish the evaluation model of power bill in RMB."

\section{References}

Ali, H., \& Abdullah, R. (2020). Fintech and financial inclusion in pakistan: an exploratory study. In Enhancing financial inclusion through islamic finance, Volume I (pp. 159-192). Springer.

Anikina, I. D., Gukova, A. V., Golodova, A. A., \& Chekalkina, A. A. (2016). Methodological aspects of prioritization of financial tools for stimulation of innovative activities.

Bharadwaj, A., El Sawy, O. A., Pavlou, P. A., \& Venkatraman, N. (2013). Digital business strategy: toward a next generation of insights. MIS quarterly, 471-482.

Chishti, S., \& Barberis, J. (2016). The fintech book: The financial technology handbook for investors, entrepreneurs and visionaries. John Wiley \& Sons.

Christensen, C. M. (2013). The innovator's dilemma: when new technologies cause great firms to fail. Harvard Business Review Press.

Cole, S., Sampson, T., \& Zia, B. (2011). Prices or knowledge? what drives demand for financial services in emerging markets? The Journal of Finance, 66(6), 1933-1967.

Dapp, T., Slomka, L., AG, D. B., \& Hoffmann, R. (2014). Fintech-the digital (r) evolution in the financial sector. Deutsche Bank Research, 11, 1-39.

Javed, A. (2019). South asia's services trade: Barriers and prospects for integration. International Journal of Management, Accounting and Economics, 6(10).

Javed, A. (2020a). Prospects and problems for E-commerce in Pakistan. Asian Journal of Economics, Finance and Management, 131-139.

Javed, A. (2020b). The scope of information and communication technology enabled services in promoting Pakistan economy. Asian Journal of Economics, Finance and Management, 1-9.

Kombe, S. K., \& Wafula, M. K. (2015). Effects of internet banking on the financial performance of commercial banks in Kenya a case of Kenya commercial bank. International Journal of Scientific and Research Publications, 5(5), 1-10.

Kumar, R., Mishra, V., \& Saha, S. (2019). Digital financial services in India: An analysis of trends in digital payment.

Lusardi, A., \& Mitchell, O. S. (2014). The economic importance of financial literacy: Theory and evidence. Journal of Economic Literature, 52(1), 5-44.

Mahmoodi, S., \& Naderi, H. (2016). Assessment of modern banking services to achieve and realization of E-commerce and its impact on the profitability of banks listed on the Tehran stock exchange. Mod Appl Sci, 10(9), 263.

Manzoor, R., Maken, A. M., Syed, S. A., \& Ahmed, V. (2018). Trading with india: some current impediments for Pakistan. Journal of International Trade Law and Policy.

Manzoor, R., Maken, A. M., Syed, S. A., \& Ahmed, V. (2019). Trading with india: some current impediments for pakistan. Journal of International Trade Law and Policy.

McCaffrey, M., \& Schiff, A. (2017). Finclusion to fintech: Fintech product development for low-income markets. Available at SSRN 3034175. 
Rizvi, S. K. A., Naqvi, B., \& Tanveer, F. (2018). Is pakistan ready to embrace fintech innovation? The Lahore Journal of Economics, 23(2), 151-182.

Taft, M. K., Hosein, Z. Z., Mehrizi, S. M. T., \& Roshan, A. (2013). The relation between financial literacy, financial wellbeing and financial concerns. International Journal of Business and Management, 8(11), 63.

Zulfiqar, K., Chaudhary, M. A., \& Aslam, A. (2016). Financial inclusion and its implications for inclusive growth in Pakistan. Pakistan Economic and Social Review, 54(2), 297-325. 